\title{
UNIVERSITYOF BIRMINGHAM

\section{Is Sex Comedy or Tragedy? Directing Desire and Female Auteurship in the Cinema of Catherine Breillat \\ Ince, Katherine}

DOI:

10.1111/j.0021-8529.2006.00237.x

Citation for published version (Harvard):

Ince, K 2006, 'Is Sex Comedy or Tragedy? Directing Desire and Female Auteurship in the Cinema of Catherine Breillat', Journal of Aesthetics and Art Criticism, vol. 64, no. 1, pp. 157-164. https://doi.org/10.1111/j.00218529.2006.00237.x

Link to publication on Research at Birmingham portal

\section{General rights}

Unless a licence is specified above, all rights (including copyright and moral rights) in this document are retained by the authors and/or the copyright holders. The express permission of the copyright holder must be obtained for any use of this material other than for purposes permitted by law.

- Users may freely distribute the URL that is used to identify this publication.

- Users may download and/or print one copy of the publication from the University of Birmingham research portal for the purpose of private study or non-commercial research.

- User may use extracts from the document in line with the concept of 'fair dealing' under the Copyright, Designs and Patents Act 1988 (?)

- Users may not further distribute the material nor use it for the purposes of commercial gain.

Where a licence is displayed above, please note the terms and conditions of the licence govern your use of this document.

When citing, please reference the published version.

Take down policy

While the University of Birmingham exercises care and attention in making items available there are rare occasions when an item has been uploaded in error or has been deemed to be commercially or otherwise sensitive.

If you believe that this is the case for this document, please contact UBIRA@lists.bham.ac.uk providing details and we will remove access to the work immediately and investigate. 
INCE, $\mathrm{K}$.

Is Sex Comedy or Tragedy? Directing Desire and Female Auteurship in the Cinema of Catherine Breillat

Published in

Thinking Through Cinema: Film as Philosophy

Murray Smith, Thomas E. Wartenberg (Editors)

ISBN: 978-1-4051-5411-6

June 2006, Wiley-Blackwell 


\section{Is Sex Comedy or Tragedy? Directing Desire and Female Auteurship in the Cinema of Catherine Breillat}

Over the last few years the films of Catherine Breillat have run the gauntlet of critical reaction, from condemnation as pornography dressed up as art cinema to acclaim for the audacity required and displayed by her uncompromising depictions of sex acts and female sexuality. Breillat has become a well known cinéaste and novelist (some of her films are translations of her own novels to the screen), but has been less credited as a theorist, despite the philosophical character of interviews such as 'The Absolute Opacity of Intimacy' ${ }^{1}$ and texts such as the preface to the screenplay of Romance (1999). ${ }^{2}$ She states in the latter, for example, that what she holds dear is 'making a moral cinema', but that morality in cinema is to be found not in the morality of the acts filmed, but in the moral dimension of the director's regard [look] (Breillat 1999: 8, 18). Breillat's contribution to feminist philosophy has already been noted, however, in a recent essay by Anne Gillain: 'In effect, what Breillat advocates is a symbolic reappropriation of a feminine realm that for centuries has been dissected by the imaginary of men' (Gillain 2003: 204).

In this essay, I want to draw out the philosophical implications of Breillat's depictions of sexualities and sex acts in order to set out the female auteurship I think is proposed by her film making. In arguing for Breillat's auteurship as the 'symbolic reappropriation of a feminine realm', I shall be drawing in particular on the theoretical writings of Judith Butler and Luce Irigaray.

As my title suggests, specific meanings of 'tragedy' and 'comedy' are in question in this exploration of Breillat's contribution to feminist philosophy. The understanding of 'tragedy' I shall use is Judith Butler's, outlined at the end of the section of Part 2 of Gender Trouble entitled 'Lacan, Rivière and the Strategies of Masquerade', where Butler sums up a lengthy analytic description of Lacan's concept of the Symbolic order as 'This structure of religious tragedy in Lacanian theory'. Most of the paragraph is quoted below, since it sets up the first parameter of my discussion of Breillat.

What plausibility can be given to an account of the Symbolic that requires a conformity to the Law that proves impossible to perform and that makes no room for the flexibility of the Law itself, its cultural reformulation in more plastic forms? The injunction to become sexed in the ways prescribed by the Symbolic always leads to failure and, in some cases, to the exposure of the phantasmatic nature of sexual identity itself. The Symbolic's claim to be cultural intelligibility in its present and hegemonic form effectively consolidates the power of those phantasms as well as the various dramas of identificatory failures. The alternative is not to suggest that identification should become a viable accomplishment. But there does seem to be a romanticization or, indeed, a religious idealization of 'failure', humility and limitation before the Law, which makes the Lacanian narrative ideologically suspect. (Butler 1990: 56, emphases added).

Butler expands on this interpretation of the Symbolic by describing it as a dialectic between a juridical imperative that cannot be fulfilled and an inevitable failure 'before the law' [that] recalls the tortured relationship between the God of the Old Testament 
and those humiliated servants who offer their obedience without reward'. This romanticization or religious idealization of humility is then glossed as Lacanian theory's 'structure of religious tragedy' (ibid.). This structure of religious tragedy 'undermine[s] any strategy of cultural politics to configure an alternative imaginary for the play of desires' (Butler 1990: 56). Cultural politics is prevented from aiming at an alternative imaginary or an alternative Symbolic by a certain 'structuralist legacy within psychoanalytic thinking'. The critique of the Lacanian Symbolic Butler begins in Gender Trouble is expanded to some extent in Bodies That Matter, in 1993, and even more so in Antigone's Claim ${ }^{3}$ (2000). There, Butler identifies this structuralist legacy as being behind the " "position" talk within recent cultural theory', a genesis often not known to those using that theory (Butler 2000: 18). This legacy in Lacanian and therefore feminist film and literary theory is the legacy of Levi-Strauss, and Levi-Straussian structuralist anthropology. It interdicts social and cultural change in the same way that structuralist theory revealed and exerted its separation from history and narrative. The Symbolic order of Lacanian theory can impose itself (it should be added, as Butler does, that whether it does this depends on who is speaking or whose pen is writing) with the force of a law that 'guarantees the failure of the tasks it commands' (Butler 1990: 56-7). Its purposes are perhaps 'not the accomplishment of some goal, but obedience and suffering to enforce the "subject's" sense of limitation "before the law" (ibid: 57). Like Butler, I shall be arguing here against the force and absolutism of Lacanian Symbolic law. But my argument goes beyond Butler in that I shall be using her critiques of the Lacanian Symbolic to outline a trajectory critical of psychoanalytic film theory. This trajectory will in many ways run parallel to the critiques of psychoanalytic film theory and its 'subjected' subject formulated by cognitive and other film theorists from 1988 on. ${ }^{4}$

Since I want to argue that Breillat's films have achieved and are achieving the female Symbolic envisaged by feminist theorists of the 1980s and 1990s, I shall now remain with recent commentary on the concept of the Symbolic order, but focus on its guise as a (or 'the', clearly an important use of the definite article) female Symbolic. For some time now, a female Imaginary and a female Symbolic have been positive goals set by feminist writers not just for theory, but for society and all the cultural representations that help to constitute and sustain that society. These goals can be associated particularly with the work of Irigaray, and from a British point of view, with books such as Margaret Whitford's Luce Irigaray: Philosophy in the Feminine (1991) and Teresa Brennan's edited Between Feminism and Psychoanalysis (1989). ${ }^{5}$ Whitford in fact concentrates more on the construction of a female Imaginary than a female Symbolic, but these two things are envisaged and argued as inseparable and mutually dependent (Whitford 1991: 76, 91). The route to a female Symbolic in Irigaray, however, depends on its proposed construction out of an un- but to-be-symbolized maternal-feminine best evinced by the mother-daughter relation and female genealogies. Chapter 4 of Whitford's Luce Irigaray: Philosophy in the Feminine is entitled 'Maternal Genealogy and the Symbolic', and she prefaces the section of the chapter called 'The mother-daughter relationship' by stating that representations of a maternal line or genealogy are 'the major and most significant absence in the symbolic' (Whitford 1991: 76).

Irigaray's and Whitford's line of argument can be counterposed to Butler's suggestion, in Antigone's Claim, that a deconstruction of existing symbolic structures may be a better route to take than the construction of partially existent, excluded, or invisible ones. 
Butler's suggestion of this alternative route comes when, in a recognizably Derridean move on a linguistic performative, she identifies the utterance '[But] it is the law!' as that which attributes to the law the force that the law itself is said to exercise. This utterance is 'a sign of allegiance to the law, a sign of the desire for the law to be the indisputable law, a theological impulse within the theory of psychoanalysis that seeks to put out of play any criticism of the symbolic father, the law of psychoanalysis itself' (Butler 2000: 21). 'Thus the status given to the law is precisely the status given to the phallus, the symbolic place of the father, the indisputable and incontestable' (ibid.). This statement should perhaps be read more as an implication of how the symbolic place of the father may be undone than a suggestion that it should be. Butler proceeds carefully, using rhetorical questions to imply that accepting the law as a final arbiter of kinship life is 'to resolve by theological means the concrete dilemmas of human sexual arrangements that have no ultimate normative form' (ibid.).

The theoretical analysis accompanying Butler's reading of Antigone (Sophocles' play and the readings of it made by Hegel, Irigaray and Lacan respectively) can be set alongside the discussion in Gender Trouble that leads up to her identification of the structure of religious tragedy in Lacanian theory. In 'Lacan, Rivière and the Strategies of Masquerade', Butler extracts two very different tasks (a term carrying important theoretico-political weight) from Lacan's analysis of Joan Rivière's famous essay 'Femininity as Masquerade'. Here, she says, “On the one hand, masquerade may be understood as the performative production of a sexual ontology, an appearing that makes itself convincing as a "being"; on the other hand, masquerade can be read as a denial of a feminine desire that presupposes some prior ontological femininity regularly unrepresented by the phallic economy” (Butler 1990: 47).

In the next paragraph Butler is already concluding that these two 'alternative directions... are not as mutually exclusive as they appear', but first, she suggests that the first task would 'engage a critical reflection on gender ontology as parodic (de)construction and, perhaps, pursue the mobile possibilities of the slippery distinction between "appearing” and "being”" (ibid.). In my reading of Breillat's cinema, I shall engage just such a critical reflection. By concentrating on the gender ontology that appears to govern feminine and masculine sexual identities in Sex Is Comedy (2002), I shall reveal the masquerade that is producing it. Sex Is Comedy, and especially the scene of 'deflowering' of the Actress (Roxane Mesquida) by the Actor (Grégoire Colin), appears to deal in fixed sexual identities. But the fact that a prosthetic and not a real penis is worn by the Actor for this scene is the clue to the fact that something quite different is going on - that the phallic mastery that would deflower the Actress is a masquerade, an 'appearing that makes itself convincing as a "being"' (op. cit.). Pursuing the philosophical possibilities of the distinction between "appearing" and "being" in Sex Is Comedy in this way will return me, first, to tragedy and to comedy, since Butler states that exploiting the potential of the distinction between appearance and being is 'a radicalization of the "comedic" dimension of sexual ontology only partially pursued by Lacan'. (Presumably, what Butler means by this is that her own work on the subversive or parodic activities of drag and cross-dressing gives much more attention to the cultural comedy of sexual ontology than Lacan ever did.) 
Sex Is Comedy is, first and foremost, a self-reflexive meditation on Breillat's working methods as a director, and particularly as a director of explicit sex scenes: the film being shot, Scènes Intimes, resembles Breillat's previous film A ma soeur! (2001). In its selfreflexivity Sex Is Comedy bears a resemblance to Truffaut's La nuit américaine (1973) and a stronger one to Abbas Kiarostami's Through the Olive Trees (1994), itself a meditation on his And Life Goes On...(1992). In a sense the film is an autofiction, ${ }^{6}$ in which the central character is Breillat's fictional incarnation Jeanne, impressively played by Anne Parillaud in what the actress herself says was her best experience of being directed since Luc Besson's 1990 film Nikita (Frappat and Lalanne 2002: 36). Breillat's interviewers in Cahiers du cinéma call it self-portraiture (ibid: 34), and Breillat herself says 'To begin with, I thought I would be making a film like La nuit américaine. I didn't imagine the dimension of self-portraiture' [Au départ, j'imaginais tourner un film comme La nuit américaine. Je n'imaginais pas cette dimension d'autoportrait' (ibid: 37)]. In my view, however, Sex Is Comedy is not a conventional autofiction, not any kind of autobiography - which Breillat says she hates (ibid: 36). The film does not concentrate on the character resembling Breillat, as a conventional autofiction would do, and its narrative is limited to one episode, the shooting of the film Scènes Intimes. The aspects of Breillat it reveals and draws out are her desire to direct and the agency with which she does so - the investment she has as a creative artist in cinema, and the transformation of her wish to convey explicit sex to audiences intelligently. This is confirmed particularly at the end of the film, when the central, most taxing scene of Scènes Intimes is 'in the can', and Jeanne is relieved and happy, even reservedly jubilant, and is pictured energetically and warmly embracing Roxane Mesquida, also her leading actress in $A$ ma soeur!

Breillat has noted that Sex Is Comedy'is also a comedy in the 'comic' sense of the term' [est aussi une comédie, au sens comique du terme (Frappat and Lalanne 2002: 37)]. (She thus distinguishes between a comedy of laughter and 'comedy' as an activity involving fictional representations, the sense drawn on by Butler when she refers to the 'comedic' dimension of sexual ontology.) The comedy of laughter may not be the primary sense of the word as it figures in the title of Breillat's film, but as she says, she did mean this sense to be included. Which it certainly is when the Actor in Breillat's scène intime trots around the set waggling the prosthetic penis manufactured for him by the props manager in order to defuse the tension created for the entire crew by intense acting and filming, since the crew all laugh hilariously. (Colin wears the prosthesis both to maintain an erection and to ensure no skin contact with Roxane Mesquida, so in contrast to Romance, where audiences and critics speculated that sex was really going on between Caroline Ducey and Rocco Siffredi, Breillat's fictional representative assures them here that it is not.) Laughter also arises spontaneously in the opening 'beach' scene of Sex Is Comedy from the misery of two scantily clad actors and an entire crew trying to create an atmosphere of oblivious sexual passion in a freezing Atlantic wind. To bring out the feminist theoretical implications of Breillat's play with literary or dramatic genres in her films up to Sex Is Comedy, I shall now briefly review the structure of tragedy in three of her earlier films, Une vraie jeune fille (1976), 36 fillette (1987), and Parfait Amour! (1996). 
Une vraie jeune fille and 36 fillette are Breillat's two studies of adolescent femininity, both pervaded by an atmosphere of confinement and attempted rebellion against the confinement through underage sex. The languours of Alice's (Charlotte Alexandra) summer vacation with her parents on a rural smallholding in Une vraie jeune fille are if anything exceeded by the pain, mistrust and wild behavior of Lili (Delphine Zentout) in 36 fillette, clearly linked to undermining treatment by both her parents and physical abuse by her father. Breillat's tragedies of female desire reach their apogee in the searing irony of her title Parfait Amour! It has become something of a cliché to link men's violence against women to their often socially sanctioned desire to maintain power over them, but the violent death met by Fredérique (Isabelle Renauld) as her affair with Christophe (Francis Renaud) is briefly and rather desperately revived a while after it has ended remains Breillat's most brutal illustration of the power structures women can suffer. The sense of limitation 'before the law' characterizing life in the tragic Lacanian Symbolic is lived out in the claustrophobic structure of Parfait Amour!, in which an erotic relationship is presented as Fredérique's only route to fulfillment as a woman, and a sense of destiny if not fate hangs over the action. Fredérique does not see her tragedy coming, but the film is identified as the tragedy of her self-destructive passion for Christophe by its presentation in flashback. The film opens with the police taking a numb Christophe through the reconstruction of the crime, followed by a sequence in which Fredérique's teenage daughter confirms the couple's mutual passion and her mother's powerlessness to escape from her relationship with her younger lover.

In Romance, both tragic and comic modes are present. Breillat says that in the opening scene 'where you see Paul (Sagamore Stévenin) all powdered up like a geisha, posing for a fashion shoot in a matador costume, it's funny' (Sklar 1999: 25) that he has to be on the tip of his toes to play the man. Gender identity is revealed to be performed in its 'essence', and comically so. On the real set of Romance, as on the fictional set of Sex Is Comedy, the crew laughed at the actors amid what is probably the most emotionally and dramatically intense scene in the film, the second of the two bondage scenes, of which Breillat says "But the really funny scene is the second scene of bondage with Robert (François Berléand), that I call the "bondage in the red dress" scene. I did it intentionally. On the set we were roaring with laughter. That's the way I wrote it. I wanted people to be able to think that a scene as weird as one about bondage and sadomasochism could be cheerful and convivial' (ibid.).

We can now extend and deepen this examination of the interplay of comedy and tragedy in Romance and Sex Is Comedy to Butler's double reading of masquerade's part in sexual ontology. The opening shots of Romance, where Paul models a matador, show that masquerade in Breillat's cinema relates to masculine gender roles and identities as much as to feminine ones. A more significant instance of masquerade, however, occurs in the scenes with Grégoire Colin's prosthetic penis, where it is the phallus 'itself', signifier of the 'indisputable and incontestable' law of the father, whose ontological status is contested. The phallus as masquerade is the point in Sex Is Comedy at which Breillat decisively opens up the distinction between appearance and being of masculinity, in order to question the meaning and authority of the sexuality that is 'taking' the virginity of an adolescent girl. The few scenes of Sex Is Comedy where the masquerading phallus is actually visible reveal Breillat's deconstruction of the symbolic structures of phallocentrism, a realization in images of what I suggested above is a Butlerian route to 
an Irigarayan female Symbolic. The scene in which Grégoire Colin comically offers his prosthesis to the assembled crew performs the "“comedic" dimension of sexual ontology' Butler finds undeveloped in Lacan, and exposes the mobility of the relationship between female auteur and male actor. This relationship is open to performative reconstruction, and by means of a close reading of the relationship between Jeanne and her unnamed male lead, I now want to link Breillat's performative cinema to the Irigarayan theory of a female Symbolic, and to the theory of female auteurship that emerges from Breillat's mise en scène of female directing in Sex Is Comedy.

In Speculum of the other Woman, Irigaray lists a number of types of female behavior that she claims can be seen as 'manifestations of a lack of an auto-erotic, homo-sexual economy' for women (Irigaray 1974: 126, Whitford's translation). What women do not have is a libidinal economy prohibited by the phallocentric Symbolic: in other words, under phallocentrism, women's desire cannot circulate as effectively as men's can. As I set out earlier when referring to Whitford's reading in her chapter 'Maternal Genealogy and the Symbolic', Irigaray's preferred argument for countering the negative effects of the phallocentric Symbolic on women's sexuality is the development of a 'homo-sexual' (same sex) economy among women, an economy to be constructed out of female genealogies and the mother-daughter relationship. But Whitford also refers to another way of changing current sexual economies for the benefit of women's sexuality described by Irigaray: this is to create an economy 'of the death drives' (Irigaray 1974: 126, Whitford's translation), the mobilization of which is currently prohibited 'for/in female sexuality'. Women's 'nature' has been constructed by a particular symbolic organization, in which it is 'used' for the representation and sublimation of men's death drives, but is unable to sublimate or represent itself.

A phallocentric symbolic economy allows the representation and sublimation of men's death drives, but not the 'rechannelling, metaphorization or sublimation' (ibid.) of women's. The concept of the death drive is specific to psychoanalysis, but here I am calling upon it to make an argument about sociosymbolic organization, not about the psyche. ${ }^{7}$ As Whitford says, Irigaray's critics read her as if she were offering an alternative psychoanalytic theory, when in fact she is 'interrogating psychoanalytic conceptualization itself' (Whitford 1991: 84). 'Lacanians take Irigaray to be talking about feminine specificity at the level of the drives, whereas I take her to be talking about feminine specificity at the level of the symbolic, or representation' (ibid: 85 ). ${ }^{8}$

A redistribution of the death drives of men and women would create at least the conditions of possibility for a female Symbolic. As Whitford states, the concept of the death drive is conceptualized differently by different psychoanalytic theorists, but its association with (self-)destructive impulses, with the drive to repeat and to return to immobility, and with sadism and masochism (phenomena pertinent to the sexualities of Breillat's cinema), means that the fundamental question involved is one of happiness and unhappiness, and to what degree these states are caused by social and psychic factors. 'Is it the fault of society or is there something inherent in the human psyche which is an obstacle to happiness? Most people would probably say 'both', but it is hard to determine with any precision what is 'inside' and what is 'outside'” (Whitford 1991: 95). I would endorse both parts of this estimation, which means that a reorganization of symbolic economies by means of a redistribution of the death drives entails broaching the large topic of the relationship of the psychic to the social. My contention, though, is that 
Breillat's representation of the directing of desire in Sex Is Comedy offers a mise en scène of this relationship - or if not of the relationship of the psychic to the social in its entirety, which can probably only be addressed discursively by philosophers and theorists, then of the enacting of desire (of the drives) in a context where the activity is representation, and, importantly, artistic representation of which a woman is in charge.

To see this, consider that from the start of filming in Sex Is Comedy, Jeanne is limping around the set due to a foot injury that has put her foot in plaster. The injury is shrouded in mystery and apparently symbolic of Oedipally disadvantaged femininity, since when asked, Jeanne says it is not she that has broken her ankle, but her ankle [pied] 'that broke itself. It's the metaphor of the film' [qui s'est cassé tout seul. C'est la métaphore du film.] As I have already emphasised, the focus of drama in Sex Is Comedy is the filming of scènes intimes between the Actress and the Actor. Interspersed with Jeanne's instruction of her actors in the movements and gestures that will produce the emotion she wants, however, are a series of tête-à-tête conversations with the Actor in which she coaxes, cajoles and bullies him into a convincing performance. In these dialogues she is outspoken to the point of being insulting, and tyrannically insistent on sex being acted as she sees it. She bans 'male larking about' [plaisanteries d'homme] from the sacred place that is her set, refuses the Actor's own interpretation of himself as 'timid', and lambasts the 'moral ugliness' [laideur morale] of an actor who performs with his body but not with his soul. The Actor is subjected to a demeaning comparison with the Actress, to which he retorts that she is no good [nulle], and that he is only interested in himself as a unique individual. This is precisely the sort of male egoism Jeanne will not indulge, and although she continues to respond to the Actor's pleas for attention (she frequently puts her arm around his waist or shoulders and walks off into the wings with him to talk things through), she will not engage in any flattery of his narcissism. She complains to her assistant director Leo (Ashley Wanninger) that the Actor is 'arrogant... terribly arrogant' [orgueilleux...atrocement orgueilleux], and, when the Actor apparently tries to sabotage the smooth running of the deflowering scene by turning Jeanne and her leading lady against one another, claiming that the Actress won't perform nude since it isn't in her contract (in the event she complies uncomplainingly), Jeanne tells him he is egoistic, vain, irresponsible and lacking in professional conscience. The Actor has said several times that he only puts up with Jeanne's authoritarianism because he is getting well paid, and now she throws his words back at him: 'Actors are very well paid for what they do because it's very hard. There, that's it' [Les acteurs sont très bien payés pour ce qu'ils font parce que c'est très dur. Voilà.]

The clashes between Jeanne and her male lead are an important dramatic focus of Sex Is Comedy, but as I have already suggested, they also illustrate the politics of desire represented in Breillat's mise-en-scène of female directing. Jeanne's foot injury symbolizes the disadvantage Breillat sees women directors as suffering by virtue of their sex, and Jeanne's passionate and often selfish involvement in her film (to prepare for the shooting of the deflowering scene, she expels the entire crew except Leo from the bedroom set for an hour-and-a-half, to allow her the solitary concentration she says artists and writers like her need) reveals iron will and determination. The character played by Grégoire Colin displays the anti-authoritarian attitude Breillat's fictional persona needs as a foil, but although some explanation for this is offered when the Actor mentions that his step-mother beat him as a child, he is in many ways an Everyman figure with the added 
sensitivity one would expect of an actor, a beautiful man who on this occasion must act out a woman's vision of male sexuality. The dialogues and relationship between Jeanne and the Actor have an unmistakably symbolic - even an allegorical - dimension. Far more than just a reenactment of a 'war of the sexes', they show uninhibited female aggression towards a male 'artist', an altered sexual economy in which the desire of a woman director is successfully sublimated, and finds its expression in the realization of her film. As will be clear by now, I am suggesting that Sex Is Comedy dramatizes the altered economy of the death drives called for by Irigaray in Speculum of the other Woman. Feminine sexualities under the sway of the death drive have figured more than once in Breillat's cinema, and particularly in the person of Marie (Caroline Ducey), the masochistic female protagonist of Romance. In Sex Is Comedy Breillat has achieved a rare degree of reflexivity about the relationship of female sexuality to artistic creation (in this case, film directing). The relationship between female director and male actor that occurs in this context may well draw on Breillat's own experience of directing, but whether it does or not, is fascinatingly suggestive about uncharted routes of women's desire. Rather than offering a general theory of female auteurship, it demonstrates how women may achieve auteurship, via an 'autofictional' mise-en-scène of Breillat's own direction of desire that viewers can recognize from her previous film.

The conclusion I wish to draw about Breillat's cinema, one illustrated particularly by her self-reflexive meditation on woman as director Sex Is Comedy, is the following. First, although Breillat herself and some of her commentators often describe her characters' sexualities as ontologies of femininity or masculinity, and thus in very essentialist terms, ${ }^{9}$ the gender identities shown in her films can be articulated along very different lines. Images of what Butler calls 'the "comedic" dimension of sexual ontology' show that the films themselves undermine this essentialism. Using Butler's theory of gender performativity to interpret masculinity as masquerade in Romance and Sex Is Comedy, along with a discussion of Breillat's bleak depictions of women's experience of sex that draws on Butler's critique of the Lacanian Symbolic, has allowed me to pursue a reading in which I have knowingly eschewed the Irigarayan approach to the masquerade Butler suggests is essentialist. ${ }^{10}$ I have, however, turned to Irigaray's notion of a female order of representation - a female Symbolic order - in order to develop my reading of the type of auteurship I think is constructed by Breillat's film making. Through her fictional persona Jeanne, Breillat shows women's film directing to be a tussle and a struggle involving an altered sexual economy, a redistribution of men's and women's death drives that allows a female director's desire to be successfully sublimated in the creation of her film. Second, I have illustrated how Breillat's cinema engages in a manner that has not been observed elsewhere with the literary modes of tragedy and comedy, in the specific senses given to the terms by Judith Butler, but also more broadly, since Butler herself draws upon literature to arrive at her definitions. Breillat's films often include stylistically intense mise en scène, but she is also a highly literary film maker, as shown in her deployment of tragic and comic registers, and by my reading of the narrative and central relationship of Sex Is Comedy. Breillat's contribution to film as philosophy is thus a feminist and literary mode of philosophizing that plumbs the 'essences' of sexualities, exposes their thoroughgoing constructedness, and suggests new and different reconstructions of gender relations. 


\section{Filmography}

A Real Young Girl/Une vraie jeune fille, 1976

Nocturnal Uproar/Tapage nocturne, 1979

36 Fillette, 1987

Dirty Like an Angel/Sale comme un ange, 1991

Perfect Love!/Parfait Amour!, 1996

Romance, 1999

Fat Girl/A ma soeur!, 2001

Brief Crossing/Brève Traversée, 2001

Sex Is Comedy, 2002

Anatomy of Hell/Anatomie de l'enfer, 2004

\section{References}

Breillat, Catherine (1999), Scénario: Romance, Paris, Petite bibliothèque des Cahiers du cinema.

Brennan, Teresa (ed) (1989), Between Feminism and Psychoanalysis, London and New York, Routledge.

Butler, Judith (1990), Gender Trouble: Feminism and the Subversion of Identity, New York and London, Routledge.

Butler, Judith (2000), Antigone's Claim: Kinship between Life and Death, New York, Columbia University Press.

Frappat, Hélène and Lalanne, Jean-Marc (2002), 'Breillat Parillaud: Auto-frictions', Cahiers du cinéma 568 (May), 34-7 and 38-9.

Gillain, Anne (2003), 'Profile of a Filmmaker: Catherine Breillat', in Célestin, DalMolin and de Courtviron (eds), Beyond French Feminisms: Debates on Women, Politics and Culture in France, 1981-2001, New York and Basingstoke, England, Palgrave Macmillan.

Sklar, Robert (1999), 'A Woman's Vision of Shame and Desire: An Interview with Catherine Breillat', Cineaste 25: 1 (December), 24-6.

Whitford, Margaret (1991), Luce Irigaray: Philosophy in the Feminine, London and New York, Routledge. Whitford, Margaret (1994), 'Irigaray, Utopia, and the Death Drive', in Carolyn Burke, Naomi Schor and Margaret Whitford (eds), Engaging with Irigaray: Feminist Philosophy and Modern European Thought, New York, Columbia Press, pp. 379-400.

1 Christine Fiszer-Guinard, 'Interview with Catherine Breillat: L’opacité absolue de l’intimité', SITES, Contemporary French and Francophone Studies 6 (2002): 5-12.

2 Catherine Breillat, Scénario: Romance (Paris: Petite bibliothèque des Cahiers du cinema, 1999).

3 Antigone's Claim: Kinship Between Life and Death (New York: Columbia University Press, 2000) is the published version of some Wellek Library lectures given at the University of California, Irvine, in May 1998.

4 For example, Noël Carroll, Mystifying Movies: Fads and Fallacies in Contemporary Film Theory, (Columbia University Press, 1988); Richard Allen, Projecting Illusion (New York: Cambridge University Press, 1995).

5 Parts 3 and 4 of Between Feminism and Psychoanalysis are entitled 'Towards another Symbolic (1): the essential thing' and 'Towards another Symbolic (2): beyond the phallus'.

6 'Autofiction' is a neologism created by the French novelist Serge Doubrovsky in 1977, which designates a variation on fictional autobiography. 'Faction' is the nearest equivalent term in English.

7 The death drive is a speculative concept invented by Freud in Beyond the Pleasure Principle in 1920, and subsequently given different formulations by analysts such as Melanie Klein. For Freud, it describes both the Wiederholungszwang or "compulsion to repeat," and the associated psychic drive towards stasis, or an 
inanimate state. The death drive is the equivalent of the Greeks' Thanatos, and Beyond the Pleasure Principle marks the point in Freud's thinking at which the opposition between the ego- and sexual instincts gives way to the tense coupling of Eros (the libido) and Thanatos (the death drive), which between them govern psychic life.

8 On Irigaray's symbolic politics and their relationship to the death drive, see also Whitford 1994.

9 For example: 'The essence of masculinity is rigidity.[...]..The essence of femininity is subtlety' (Breillat 1999: 13), or Kathleen Murphy's article entitled 'a matter of skin...Catherine Breillat's Metaphysics of Film and Flesh’, Film Comment 35 (1999): 16-20, 22.

10 '[M]asquerade can be read as a denial of a feminine desire that presupposes some prior ontological femininity regularly unrepresented by the phallic economy...the masquerade...is what women do...in order to participate in man's desire, but at the cost of giving up their own.' Butler, Gender Trouble, p.47. 